University for Business and Technology in Kosovo

UBT Knowledge Center

Oct 27th, 1:30 PM - 3:00 PM

\title{
Evaluation of Lead Concentration on Agriculture Surface Soil around the Former Battery Production, Berat, Albania
}

\author{
Mirela Alushllari \\ University of Tirana, m.alushllari@gmail.com \\ Nikolla Civici \\ University of Tirana
}

Follow this and additional works at: https://knowledgecenter.ubt-uni.net/conference

Part of the Food Science Commons

\section{Recommended Citation}

Alushllari, Mirela and Civici, Nikolla, "Evaluation of Lead Concentration on Agriculture Surface Soil around the Former Battery Production, Berat, Albania" (2018). UBT International Conference. 167.

https://knowledgecenter.ubt-uni.net/conference/2018/all-events/167

This Event is brought to you for free and open access by the Publication and Journals at UBT Knowledge Center. It has been accepted for inclusion in UBT International Conference by an authorized administrator of UBT Knowledge Center. For more information, please contact knowledge.center@ubt-uni.net. 


\title{
Evaluation of Lead Concentration on Agriculture Surface Soil around the Former Battery Production, Berat, Albania
}

\author{
${ }^{1 *}$ Mirela Alushllari, ${ }^{1}$ Nikolla Civici, \\ Institute of Applied Nuclear Physics, University of Tirana, Albania. \\ m.alushllari@gmail.com
}

\begin{abstract}
A study was performed to investigate the distribution of lead concentration on the surface soils samples at a distance $80-2000 \mathrm{~m}$ around the former Factory Production of Batteries to Berat, Albania. There were two goals of this study: to assessment of the environmental and impact of the industrial lead waste in the surface soil around the former Factory of Battery Production; and comparison the concentration of lead in the planted areas where the inhabitants cultivate agricultural products with untreated surface soil. To achieve the goals of the work, initially are selected 33 surface sampling points of soil. 20 of them represent the untreated soils and other 13 represent soil samples where the plants are cultivated. All the representative soil samples were analyzing using Atomic Absorption Spectrometry for their lead content, in Institute of Applied Nuclear Physics, University of Tirana, Albania. From results obtained the fraction of lead in surface soil samples ranged from 78 $\mathrm{mg} / \mathrm{kg}$ to $24207 \mathrm{mg} / \mathrm{kg}$ and average concentration of lead was $1821 \mathrm{mg} / \mathrm{kg}$. Concentration of lead in uncultivated soil samples was found higher than the concentration of lead in cultivated surface soil samples, soils which have been worked for cultivated crops. The fraction of lead in soil samples that are collected at different points are compared with the MCL specified by the Directive 86/278/EEC. Also, we have calculated factor of Hazardous Quoted for each sampling point.
\end{abstract}

Keywords: lead, surface soil samples, Atomic Absorption Spectrometry

\section{Introduction}

Lead can enter the human body through food, water, and air [1]. The presence of lead and other heavy metals in environment is dangerous because they have tendency to bioaccumulate [2]. Lead is known as one of the most toxic heavy metals in the environment [3]. The high level of lead has a negative impact on the natural environment. Serious human health risks are associated with lead poisoning [4]. The sources of emission of lead in the environment are natural and anthropogenic [5]. Over the years lead is extracted from the mines for different purposes, such as: production of batteries, half-done production of metallic sheets and pipes, alloys, additive in benzene, in PVC, in ammunitions [6]. Since lead is mostly used for the production of batteries, the major pollution comes exactly from this industry. In 
general, areas close to Factory of Battery Production are presented with environmental problems, due to increased production and consumption of lead from vegetation and livestock [7]. As a result, the contamination of soils has influence on the increase of the level of lead in vegetation [8]. The high levels of exposure to $\mathrm{Pb}$ result in biochemical and toxic effects on the people [9]. The environmental protection should be and remain the main goal and task of the society. The complex of Factory for the production of batteries in Berat, Albania has begun its activity in 1970. It was designed to produce batteries for passengers' cars and trucks and technical equipment. The Battery Factory conducted its activity as a state-run factory for about 20 years [10]. The level of lead in soil samples was compared to the values recommended by the European Community according to Directive 86/278 EEC [11] and was calculated the potential of risk by USEPA [12].

\section{Material and Method}

Representative soil samples are collected at a distance $80-2000 \mathrm{~m}$ around the former Factory of Battery Production-Berat, Albania. This Factory is located in the northeastern city of Berat, with respective coordinate: 40042 ' 24.82" N and 19058 ' 59.42 ' E. During the sampling we have collected 33 surface soil samples $(0-5 \mathrm{~cm})$ where 20 were uncultivated soil and 13 cultivated soils. These sampling stations are marked in map 1, while their coordinates are presented respectively in table 1 with results.

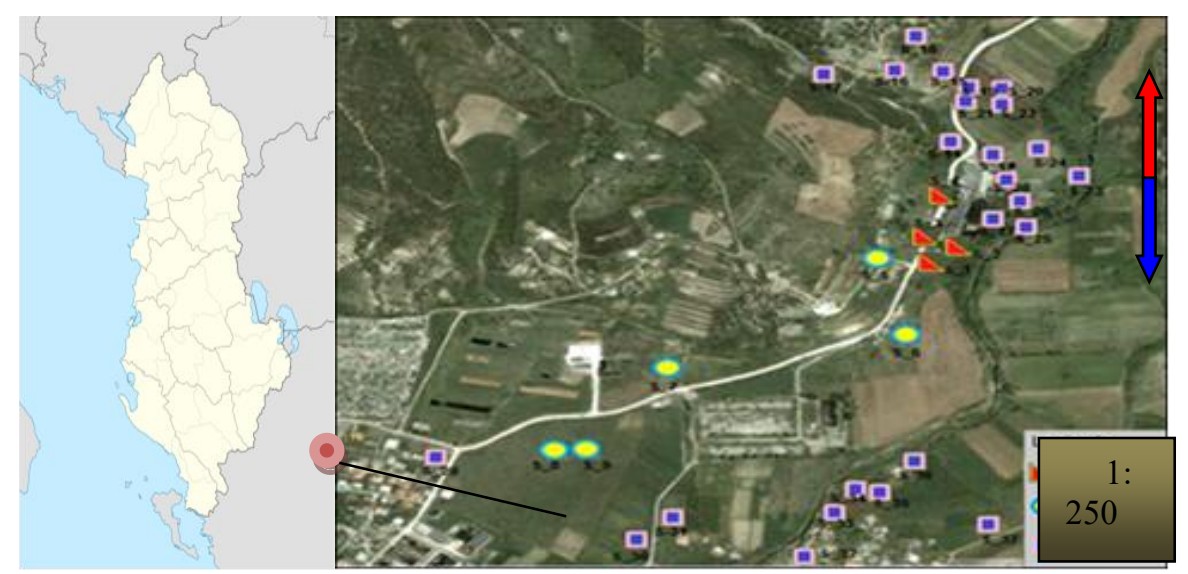

Figure 1: Map of sampling stations of soil.

Represented soil samples analyzed using Atomic Absorption Spectrometer, Aanalyst 800 Perkin Elmer with Atomic Absorption Spectrometry, Flame method [13]. HCL lamp used as radiation source for the determination of lead according recommended conditions. Acids used for the digestion of samples, stock solutions of lead have high grade purity. Glass and Teflon vessels used were treated with solution 
$10 \% \mathrm{v} / \mathrm{v}$ nitric acid, for 24 hours and then washed with water bidistilled. Instrumental conditions for lead are based on AMAAS, from Perkin Elmer [13] Digestion soil samples are prepared using a procedure recommended by EPA, Method 3050B [14]. Three applications were carried out for the measurement of calibration standards and measurement of samples. For each element calibration curve equation is linear and passing through point zero. A quality control material IAEA- Soil 7 was analyzed in parallel with the soil samples and IAEA_336 Lichen was analyzed in parallel with the biological samples. To check the instrumental drift, an aqueous standard solution was analyzed after every three-five samples.

\section{Results and Discussions}

The measurements obtained by analyzing the soil samples are presented in the table 1. In this table are presented: sampling points, code in AAS, coordinates, mean concentration of lead, SD in representative surface soil samples. From results obtained we have calculated factor of HQ according US EPA-2006, for representative surface soil samples, their values ranged from 0.4 to 80.7 .

Table 1. Sampling points and concentration of lead in surface soil and calculated of HQ

\begin{tabular}{|c|c|c|c|c|c|c|}
\hline $\begin{array}{l}\text { Sampling } \\
\text { point }\end{array}$ & $\begin{array}{l}\text { Code } \\
\text { AAS }\end{array}$ & Material & Nord & East & $\begin{array}{l}\mathrm{Pb}(\mathrm{mg} / \mathrm{kg}) \\
\pm \mathrm{SD}\end{array}$ & HQ \\
\hline S_1 & $\mathrm{P} 1 \mathrm{~T} 1$ & Surface soil_UC & $40^{\circ} 42^{\prime \prime} 21.32^{\prime}$ & $19^{0} 58^{\prime \prime} 56.74^{\prime}$ & $3008 \pm 33.09$ & 10.0 \\
\hline $\mathrm{S} \_2$ & $\mathrm{P} 2 \mathrm{~T} 1$ & Surface soil_UC & $40^{\circ} 42^{\prime \prime} 21.61^{\prime}$ & $19^{0} 58^{\prime \prime} 57.63^{\prime}$ & $5663 \pm 7.36$ & 18.9 \\
\hline S_3 & P3 T1 & Surface soil_UC & $40^{\circ} 42^{\prime \prime} 22.40^{\prime}$ & $19^{0} 58^{\prime \prime} 57.68^{\prime}$ & $1135 \pm 41.98$ & 3.8 \\
\hline S_4 & $\mathrm{P} 4 \mathrm{~T} 1$ & Surface soil_UC & $40^{\circ} 42^{\prime \prime} 24.18^{\prime}$ & $19^{0} 58^{\prime \prime} 58.01^{\prime}$ & $5511 \pm 22.04$ & 18.4 \\
\hline S_5 & P5_T1 & Surface soil_UC & $40^{\circ} 42^{\prime \prime} 22.08^{\prime}$ & $19^{0} 58^{\prime \prime} 55.57^{\prime}$ & $397 \pm 3.00$ & 1.3 \\
\hline S_6 & P6_T1 & Surface soil_UC & $40^{\circ} 42^{\prime \prime} 15.54 "$ & $19^{0} 58^{\prime \prime} 53.06^{\prime}$ & $856 \pm 24.81$ & 2.9 \\
\hline S_7 & P7_T1 & Surface soil_C & $40^{\circ} 42^{\prime \prime} 14.45^{\prime}$ & $19^{0} 58^{\prime \prime} 53.43^{\prime}$ & $333 \pm 19.32$ & 1.1 \\
\hline S_8 & P8_T1 & Surface soil_C & $40^{\circ} 42^{\prime \prime} 09.06^{\prime}$ & $19^{0} 58^{\prime \prime} 35.89^{\prime}$ & $105 \pm 6.53$ & 0.4 \\
\hline S_9 & P9_T1 & Surface soil_C & $40^{\circ} 42^{\prime \prime} 09.23^{\prime}$ & $19^{0} 58^{\prime \prime} 36.65^{\prime}$ & $329 \pm 35.15$ & 1.1 \\
\hline S_10 & P10_T1 & Surface soil_C & $40^{\circ} 41^{\prime \prime} 58.97^{\prime}$ & $19^{0} 58^{\prime \prime} 23.74^{\prime}$ & $200 \pm 23.64$ & 0.7 \\
\hline S_11 & P11_T1 & Surface soil_C & $40^{\circ} 41^{\prime \prime} 58.66^{\prime}$ & $19^{0} 58^{\prime \prime} 22.29^{\prime}$ & $210 \pm 18.67$ & 0.7 \\
\hline S_12 & P12_T1 & Surface soil_UC & $40^{\circ} 42^{\prime \prime} 04.20^{\prime}$ & $19^{0} 57^{\prime \prime} 58.50^{\prime}$ & $139 \pm 3.61$ & 0.5 \\
\hline S_13 & P13_T1 & Surface soil_UC & $40^{\circ} 42^{\prime \prime} 04.20^{\prime}$ & $19^{0} 58^{\prime \prime} 00.48^{\prime}$ & $\begin{array}{l}177 \pm 5.67 \\
24207 \pm 11.0\end{array}$ & 0.6 \\
\hline S_14 & P14_T1 & Surface soil_UC & $40^{\circ} 42^{\prime \prime} 27.26^{\prime}$ & $19^{0} 58^{\prime \prime} 59.67^{\prime}$ & 0 & 80.7 \\
\hline S_15 & P15_T1 & Surface soil_UC & $40^{\circ} 42^{\prime \prime} 33.45^{\prime}$ & $19^{0} 58^{\prime \prime} 57.86^{\prime}$ & $350 \pm 3.00$ & 1.2 \\
\hline S_16 & P16_T1 & Surface soil_UC & $40^{\circ} 42^{\prime \prime} 34.04^{\prime}$ & $19^{0} 58^{\prime \prime} 53.05^{\prime}$ & $342 \pm 12.00$ & 1.1 \\
\hline S_18 & P18_T1 & Surface soil_UC & $40^{\circ} 42^{\prime \prime} 35.44^{\prime}$ & $19^{0} 58^{\prime \prime} 56.36^{\prime}$ & $244 \pm 0.20$ & 0.8 \\
\hline S_19 & P19_T1 & Surface soil_UC & $40^{0} 42^{\prime \prime} 31.29^{\prime}$ & $19^{0} 58^{\prime \prime} 58.87^{\prime}$ & $951 \pm 28.00$ & 3.2 \\
\hline
\end{tabular}




$\begin{array}{lllllll}\text { S_20 } & \text { P20_T1 } & \text { Surface soil_UC } & 40^{0} 42^{\prime \prime} 31.81^{\prime} & 19^{0} 58^{\prime \prime} 59.00^{\prime} & 1203 \pm 22.00 & 4.0 \\ \text { S_21 } & \text { P21_T1 } & \text { Surface soil_C } & 40^{0} 42^{\prime \prime} 31.33^{\prime} & 19^{0} 58^{\prime \prime} 58.80^{\prime} & 236 \pm 9.70 & 0.8 \\ \text { S_22 } & \text { P22_T1 } & \text { Surface soil_C } & 40^{0} 42^{\prime \prime} 31.03^{\prime} & 19^{0} 58^{\prime \prime} 59.08^{\prime} & 228 \pm 12.00 & 0.8 \\ \text { S_23 } & \text { P23_T1 } & \text { Surface soil_UC } & 40^{0} 42^{\prime \prime} 39.38^{\prime} & 19^{0} 59^{\prime \prime} 05.72^{\prime} & 243 \pm 9.40 & 0.8 \\ \text { S_24 } & \text { P24_T1 } & \text { Surface soil_C } & 40^{0} 42^{\prime \prime} 28.41^{\prime} & 19^{0} 59^{\prime \prime} 02.91^{\prime} & 126 \pm 1.00 & 0.4 \\ \text { S_25 } & \text { P25_T1 } & \text { Surface soil_UC } & 40^{0} 42^{\prime \prime} 23.70^{\prime} & 19^{0} 59^{\prime \prime} 02.70^{\prime} & 460 \pm 0.30 & 1.5 \\ \text { S_26 } & \text { P26_T1 } & \text { Surface soil_UC } & 40^{0} 42^{\prime \prime} 24.25^{\prime} & 19^{0} 59^{\prime \prime} 00.87^{\prime} & 742 \pm 22.00 & 2.5 \\ \text { S_27 } & \text { P27_T1 } & \text { Surface soil_UC } & 40^{0} 42^{\prime \prime} 22.67^{\prime} & 19^{0} 58^{\prime \prime} 59.83^{\prime} & 384 \pm 0.40 & 1.3 \\ \text { S_28 } & \text { P28_T2 } & \text { Surface soil_UC } & 40^{0} 42^{\prime \prime 26.21 '} & 19^{0} 59^{\prime \prime} 01.29^{\prime} & 10614 \pm 3.00 & 35.4 \\ \text { S_30 } & \text { S30_T1 } & \text { Surface soil_C } & 40^{0} 42^{\prime \prime} 04.97^{\prime} & 19^{0} 58^{\prime \prime} 42.21^{\prime} & 341 \pm 1.11 & 1.1 \\ \text { S_31 } & \text { S31_T1 } & \text { Surface soil_C } & 40^{0} 42^{\prime \prime} 06.07^{\prime} & 19^{0} 58^{\prime \prime} 43.86^{\prime} & 185 \pm 2.70 & 0.6 \\ \text { S_34 } & \text { S34_T1 } & \text { Surface soil_C } & 40^{0} 42^{\prime \prime} 08.13^{\prime \prime} & 19^{0} 58^{\prime \prime} 53.46^{\prime} & 149 \pm 0.78 & 0.5 \\ \text { S_35 } & \text { S35_T1 } & \text { Surface soil_C } & 40^{0} 42^{\prime \prime} 08.20^{\prime \prime} & 19^{0} 58^{\prime \prime} 53.33^{\prime} & 163 \pm 0.94 & 0.5 \\ \text { S_36 } & \text { S36_T1 } & \text { Surface soil_UC } & 40^{0} 42^{\prime \prime} 07.25^{\prime \prime} & 15^{0} 58^{\prime \prime} 52.39^{\prime} & 662 \pm 0.13 & 2.2 \\ \text { S_37 } & \text { S37_T1 } & \text { Surface soil_C } & 40^{0} 42^{\prime \prime} 05.09^{\prime \prime} & 15^{0} 58^{\prime \prime} 59.73^{\prime} & 187 \pm 16.30 & 0.6 \\ & & & \text { Directive } & 86 / 278 / E E C & 300 & \end{array}$

UC - soil that uncultivated plants, only random grass; C - soil that cultivated agriculture products.

The mean concentrations of lead in all surface soil samples was found on the order $78 \mathrm{mg} / \mathrm{kg}-24207 \mathrm{mg} / \mathrm{kg}$, while in uncultivated soil ranged $139-24207 \mathrm{mg} / \mathrm{kg}$ and in cultivated surface soil samples ranged $105-341 \mathrm{mg} / \mathrm{kg}$. It was observed the mean concentration of lead there is not unique distribution and the lead concentration was higher in uncultivated soil. The concentration of lead in the some of the soil samples is found very high. The highest concentration of lead was found in samples that are collected in S_1 and S_14 points. These points are very enclosing the factory and in this area have a lot of solid wastes in soil. The concentrations of lead in representative soil samples are compared with the MCL recommended by the Directive 86/278/EEC, it is $300(\mathrm{mg} / \mathrm{kg})$. The factor of HQ in representative surface soil samples is found in the order 0.42-80.69.

\subsection{Figures}

The data presented in the table 1, are presented in graphical form as below. Graph in figure 2 is presented the lead concentration which was found in representative surface soil samples while graph in figure 3 is presented the probability plot of lead in surface soil samples. 


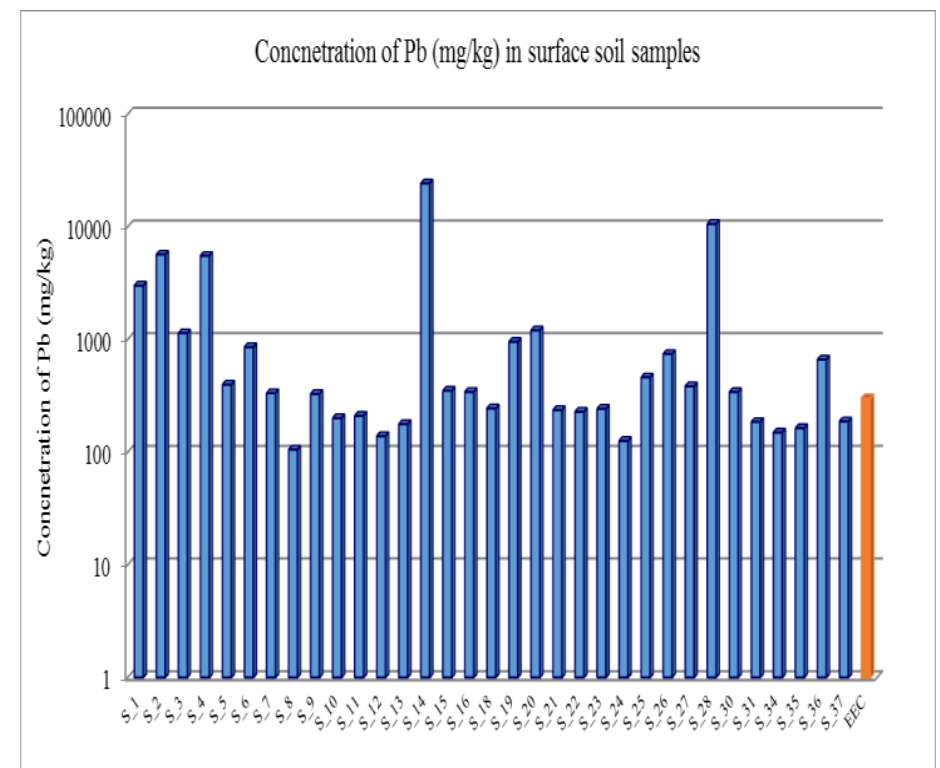

Figure 2: The mean concentration of lead in top soil.

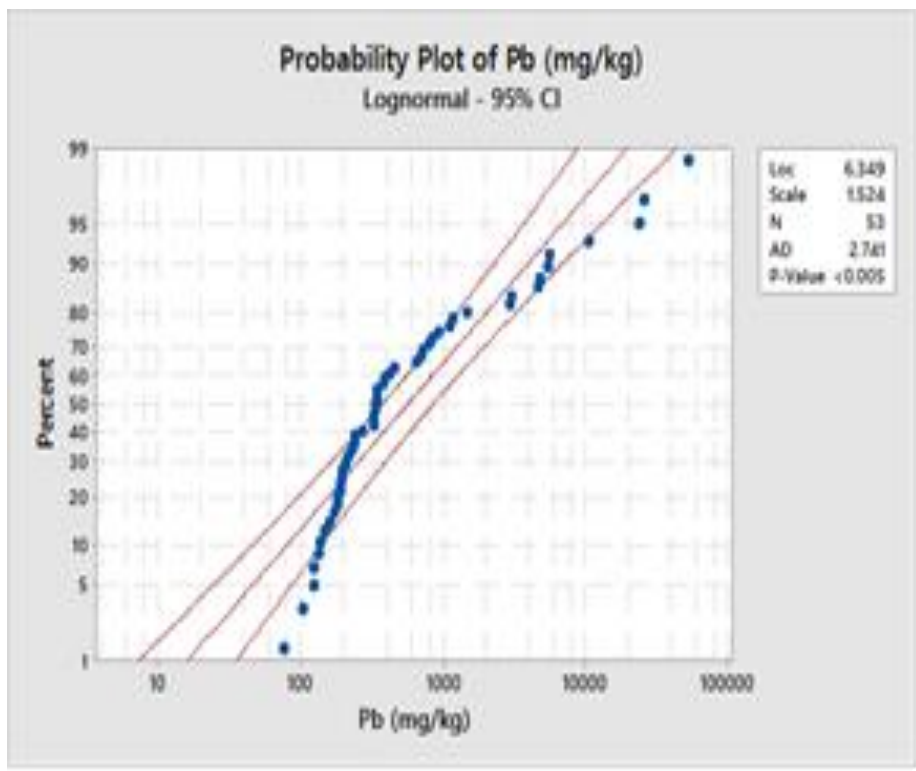

3: Probability of lead in soil samples 
Graph in figure 4 is presented the lead concentration in the soil where the inhabitants cultivate agricultural products and graph in figure 5 is presented the probability plot of lead in uncultivated, untreated surface soil samples

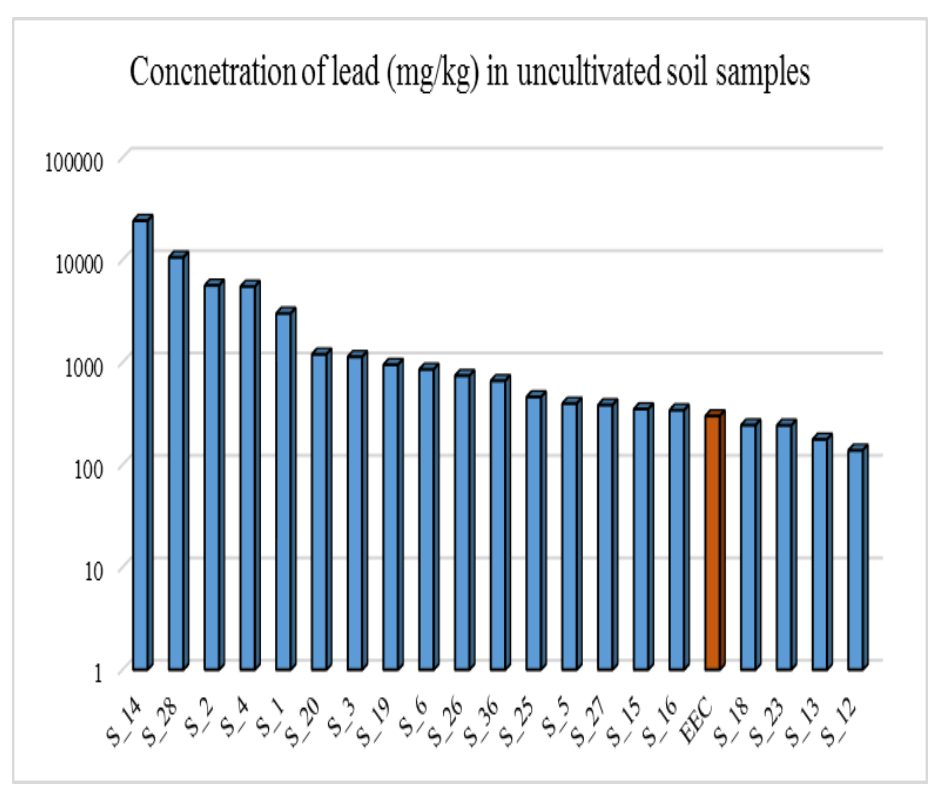

Figure 4: Level of $\mathrm{Pb}$ in uncultivated soil.

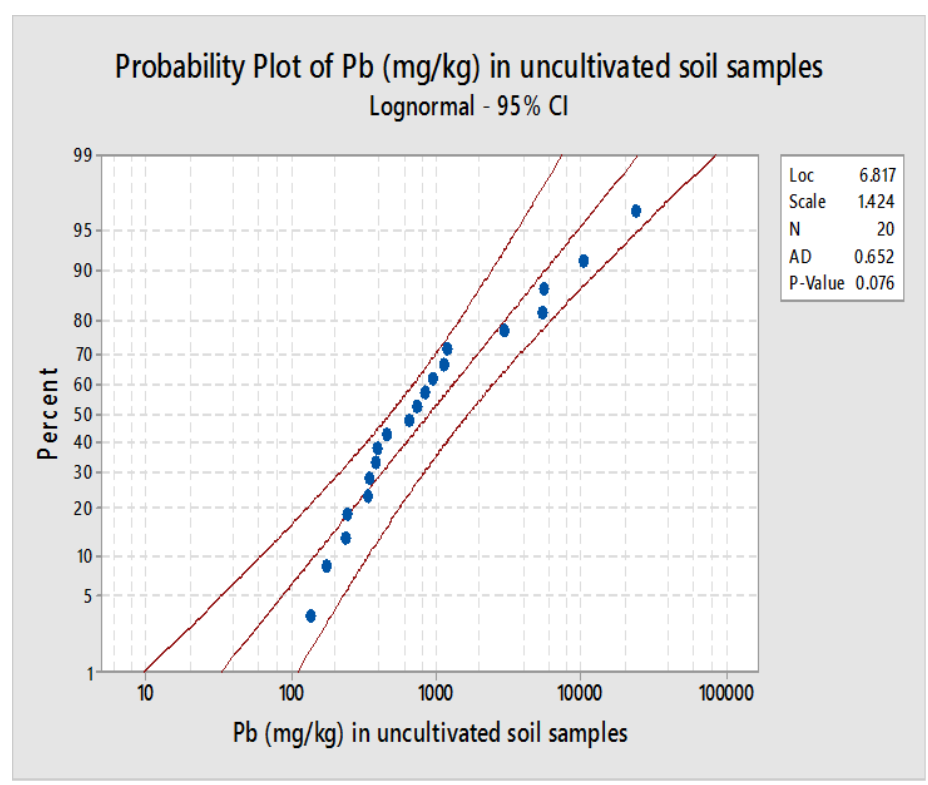

Figure 5: Probability of $\mathrm{Pb}$ in uncultivated soil. 
Graph in figure 6 is presented the concentration of lead in cultivated soil samples, while graph in figure 7 is presented Probability of $\mathrm{Pb}$ in cultivated soil samples.

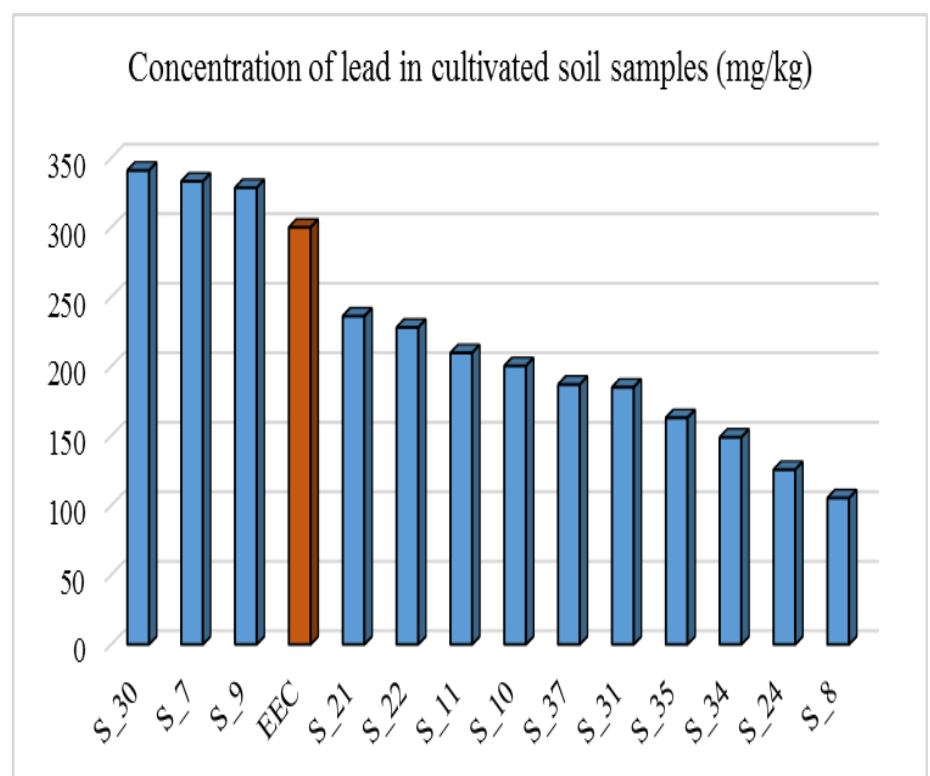

Figure 6: Lead concentration in cultivated soil.

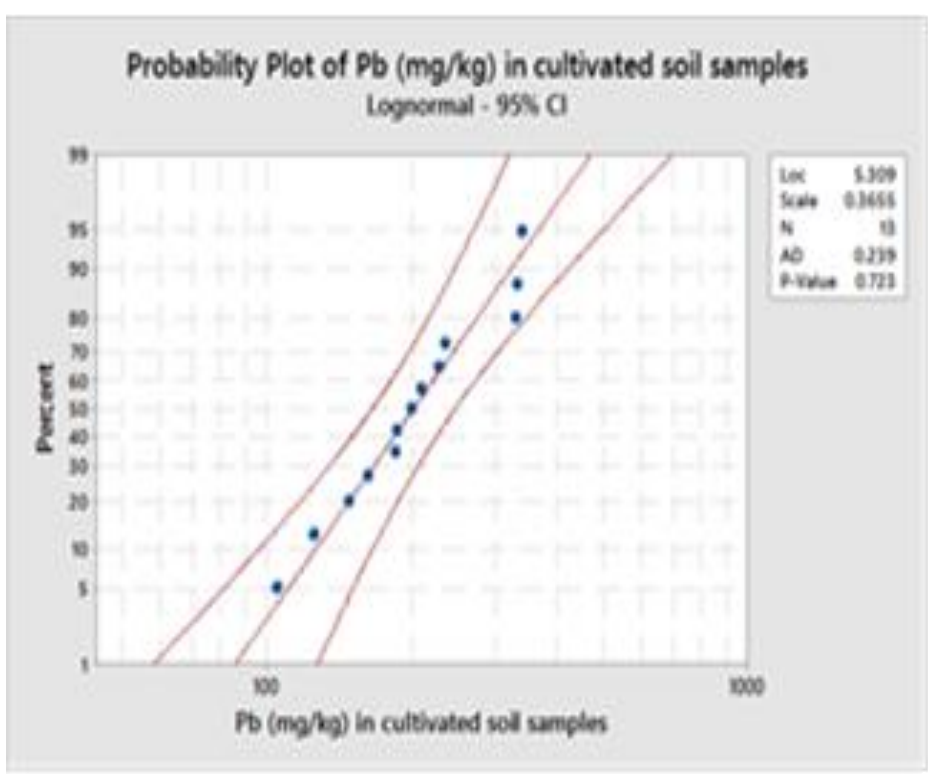

Figure 7: Probability of $\mathrm{Pb}$ in cultivated soil. 
Graphs 8 and 9 are presented counter plot of lead respectively in uncultivated and cultivated soils.

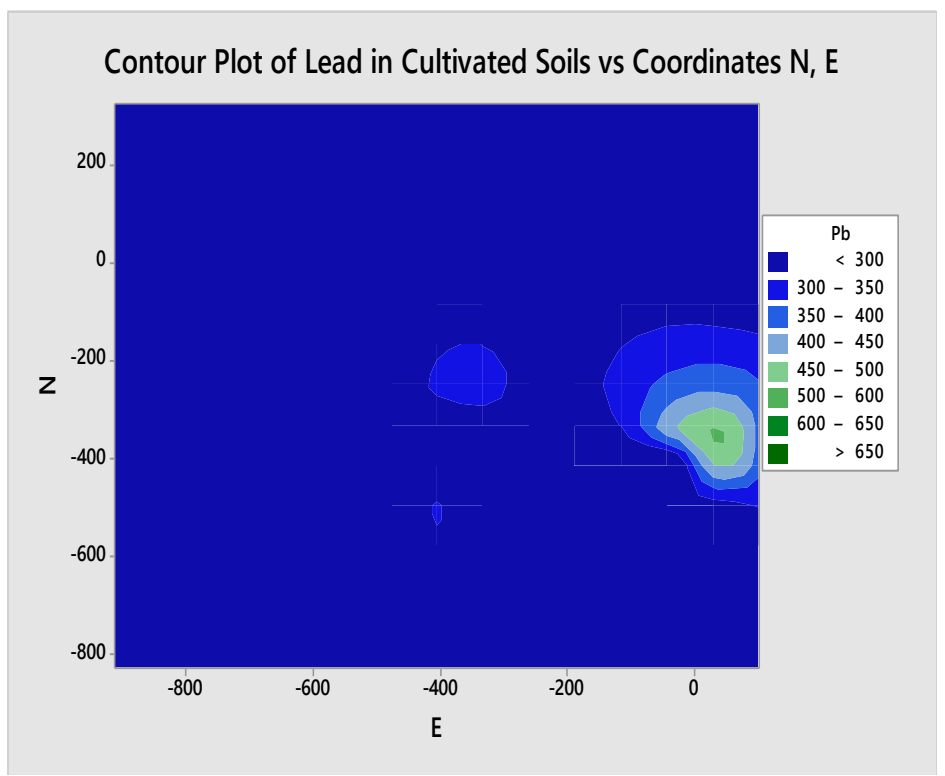

Figure 8: Lead concentration in cultivated soil.

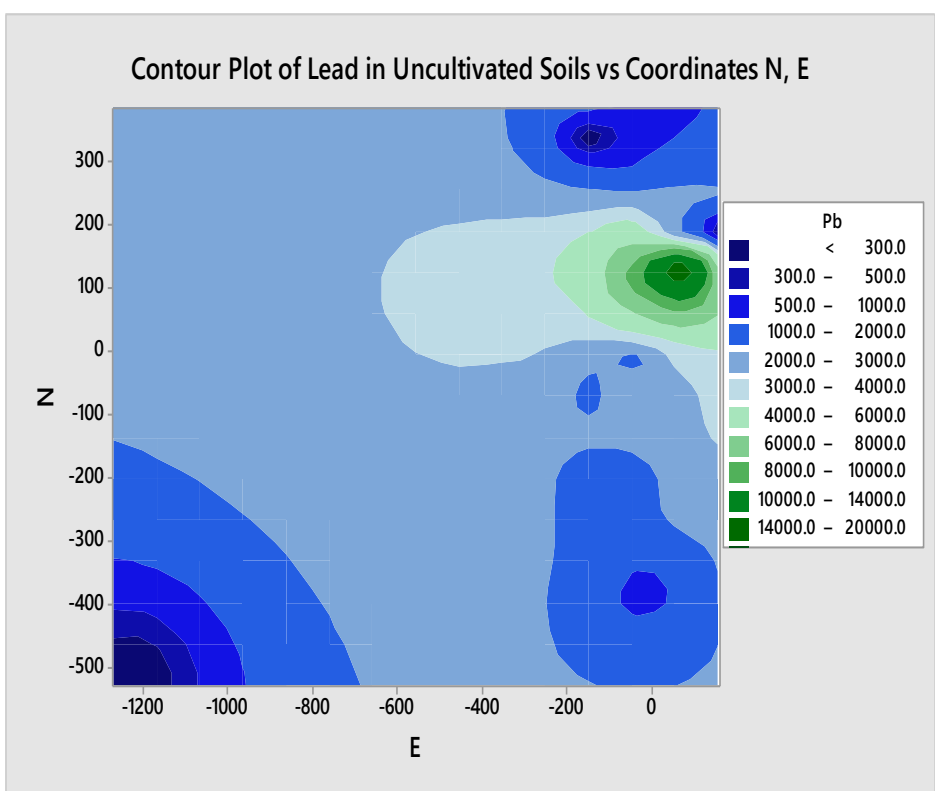

. Figure 9: Probability of $\mathrm{Pb}$ in cultivated soil 
Graph in figure 10 is presented the factor of Calculated Hazardous Quoted for lead concentration was found in all surface soil samples, while graph in figure 11 is presented dependence of lead concentration from distance of factory.

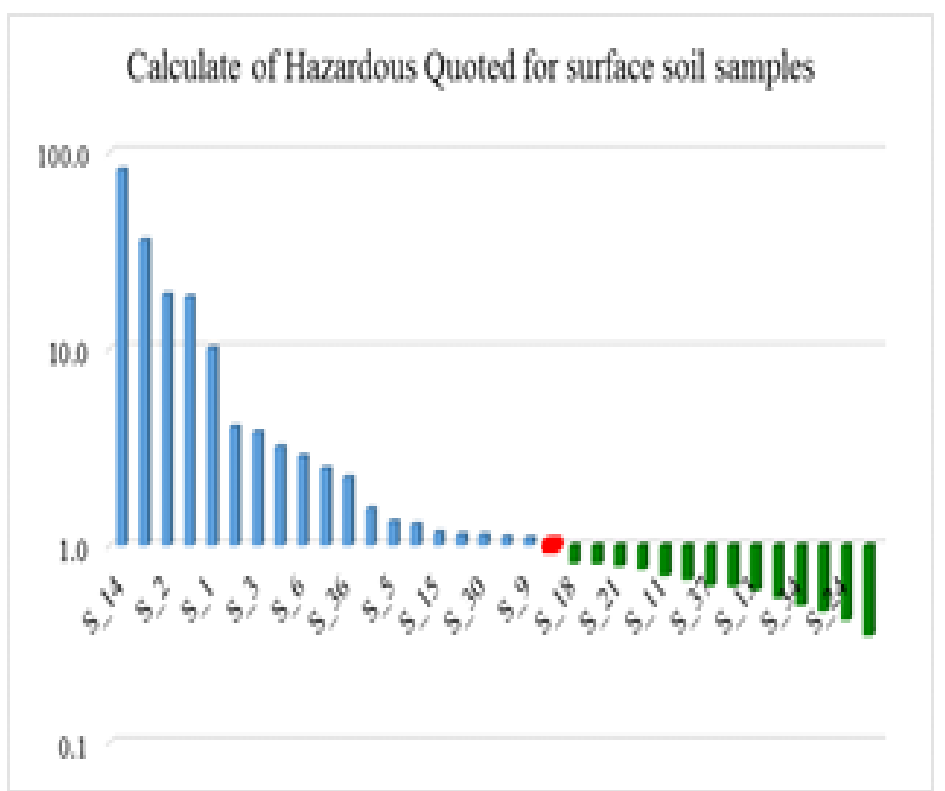

Figure 10: Calculated Hazardous Quoted of $\mathrm{Pb}$

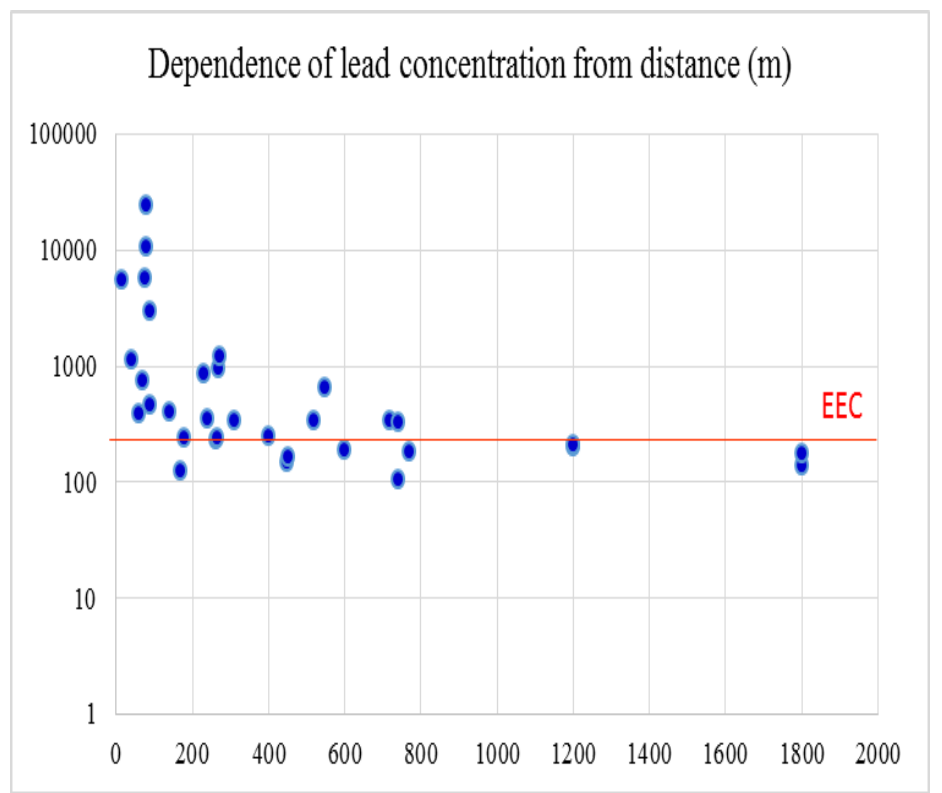

Figure 11. Dependence of lead concentration from distance. 
Graph in figure $12 \& 13$ are presented dependence of lead concentration from distance of factory, distributions of lead concentration respectively in uncultivated and cultivated surface soil samples.

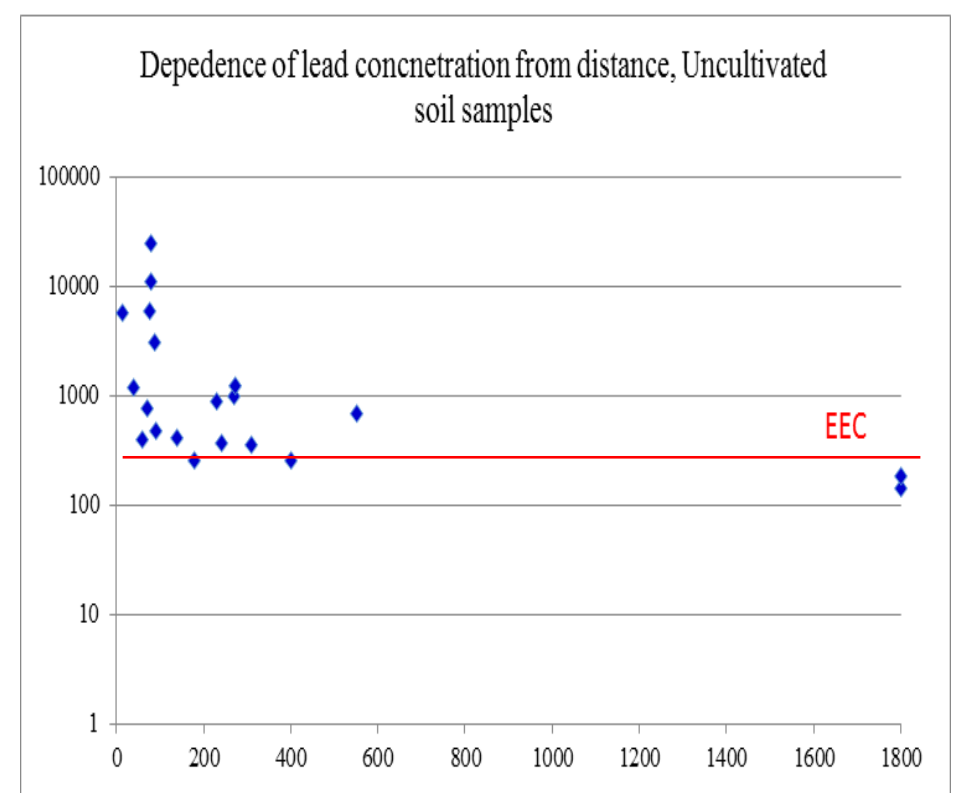

Figure 12: Distribution of $\mathrm{Pb}$ in uncultivated soil

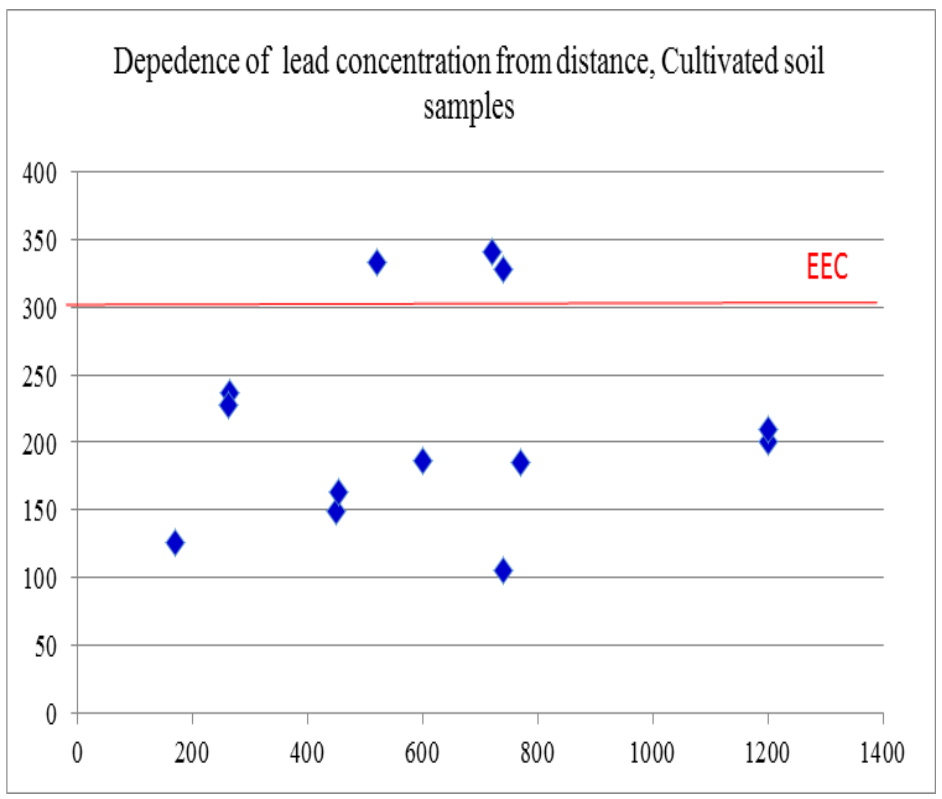

Figure 13: Distribution of $\mathrm{Pb}$ in cultivated soil 


\section{Conclusion}

Lead was present in all samples analyzed. The level of lead was found high in the representative surface soil samples. But it was observed that the concentration of lead in uncultivated soil samples was higher than in cultivated soil samples. From the results obtained it was observed that concentration of lead in 12 from 33 surface soil samples is high, concentration of lead was above the MCL, recommended by Directive 86/278/EEC for concentration of lead in soil. In these points the calculated $\mathrm{HQ}$ were high. If calculated HQ factor in surface soil samples was higher than 1, then this territory is contaminated and this contamination is associated with the negative effects to both ecological and human health. It was observed that distribution of lead depending of distance from factory is decreased to about 400-500 $\mathrm{m}$ distance from the factory. The presence of lead in high concentration in representative soil samples was contributed by industrial waste as a result of the activity of the factory.

\section{Acknowledgements}

This work is part of my thesis of PhD. My appreciation is send to Institute of Applied Nuclear Physics; to Faculty of Natural Sciences, University of Tirana and to my Family. Thank you for your endless support.

\section{Abbreviations used:}

AAS (Atomic Absorption Spectrometry); C (cultivated soil samples); EEC (European Economic Community); EPA (Environmental Protection Agency); HCL (Hollow cathode lamps); HQ (Hazardous Quoted); IAEA (International Atomic Energy Agency); MCL (Maximum Contaminant Levels); PVC (Polyvinyl chloride); SD (Standard deviation); UC (uncultivated soil samples); USEPA (United States Environmental Protection Agency).

\section{References}

1. Alushllari M. and Civici N (2014). Assessment of lead accumulation by leaves of Cynadon dactiyon and needles of Pinus pinea. Proceeding Book: Physical Chemistry, Belgrade 2014.

2. Censi P, Spoto SE, Saiano F, Sprovieri M, Mazzola S, Nardone G, Di Geronimo SI, Punturo R, Ottonello D, (2006). Heavy metals in coastal Water system. Chemosphere 64: page1167-1176.

3. Alushllari M. and Civici N (2014). Analyses of $\mathrm{Cd}, \mathrm{Cr}$ and $\mathrm{Pb}$ concentration in the aerosols using different digestion methods. Proceeding book. Pg. 44-48. ISBN: 978-960-524-430-9.

4. Alushllari, M. and Civici, N. (2016). Mechanical Engineering - Scientific Journal, Vol. 34, No. 1, pp. 113-118 (2016). In print: ISSN 1857-5293. 
5. Carpenter SR, Caraco NF, Correll DL, HoWarth RW, Sharpely AN, Smith VH, (1998) Nonpoint Pollution of surface Waters With phosphorus and nitrogen, Ecological Applications. 8, 559-568.

6. Demayo, A., M.C. Taylor, K.W. Taylor, and P.V. Hodson. 1982. Toxic effects of lead and lead compounds on human health, aquatic life, wildlife plants, and livestock. Critical Reviews in Environmental Control, 12:257-305.

7. Alushllari, M. and Civici, N. (2015). Verification of Penetration of Lead in the Profile of Soil around the Former Battery Production Factory, Berat Albania. Journal of Environmental Protection, 2015, 6, 388-398 Published Online April 2015 in SciRes. http://dx.doi.org/10.4236/jep.2015.64038.

8. Zakrzewski SF (2002). Environmental Toxicology.3Rd Edition.Oxford University Press. USA, pp.5- 45.

9. Aigbedion LN (2005). Environmental Pollution in the Niger Delta, Nigeria. Inter Disciplinary J. Enugu Niger., 3 (4). Page 205-210.

10. Mirela Alushllari (2013). http://www.fshn.edu.al/mirela-alushllari. https://docs.google.com/a/fshn.edu.al/viewer?a=v\&pid=sites\&srcid=ZnNobi5lZHUuYWx8 ZnNobnxneDo1MGZmNzM5MWYzZmRjODYz. Page 41-43.

11. EEC, Economic European Communities. (2006). The Council Directive 86/278/EEC on protection of the environment.

12. U.S. EPA. (Environmental Protection Agency) 2006. Risk Assessment Guidance for Superfund Volume I: Human Health Evaluation Manual (Part E, Supplemental Guidance for Dermal Risk Assessment), Final. EPA/540/R/99/005. Office of Solid Waste and Emergency Response, Washington, DC. PB99-963312

13. (Perkin-Elmer Corp. 1991-1999). Perkin-Elmer Corp.: 1964-2000, Analytical Methods for Atomic Absorption Spectrophotometry \& Recommended conditions for THGA furnaces

14. EPA3050B, http://www.epa.gov/osw/hazard/testmethods/sw846/pdfs/3050b.pdf. 